\section{Aus den Hochschulen}

Vom 13. bis 15. September 2007 fand die 20. Jahrestagung des Arbeitskreises "Wirtschaftsinformatik an Fachhochschulen (AKWI)" an der Hochschule in Fulda statt. Beim AKWI handelt es sich um den internationalen Dachverband der Fachbereiche an Fachhochschulen mit deutschsprachigen Wirtschaftsinformatik-Studiengängen oder -Schwerpunkten. Das Programm der Tagung beinhaltete eine wissenschaftliche Fachtagung unter dem Titel „Herausforderungen an die Wirtschaftsinformatik: Wissensmanagement, E-Business und ereignisgesteuerte Geschäftsprozesse in Echtzeit" und einen hochschulpolitischen Teil mit einem Erfahrungsaustausch über die Rahmenbedingungen der gemeinsamen Arbeit. Bei weitergehendem Interesse an diesem Gegenstand kann man den Inhalt des Tagungsbandes unter http://opus.kobv.de/tfhwildau/volltexte/ 2007/16/pdf/AKWI_Tagungsband2007.pdf und die weiteren Ergebnisse des hochschulpolitischen Teils der Tagung unter

http://www.akwi.de, aus dem Netz beziehen.

PD Dr. Franz Rothlauf, Jahrgang 1971, hat den Ruf auf die Professur für Wirtschaftsinformatik und BWL an der Universität Mainz angenommen (vgl. WIRTSCHAFTSINFORMATIK 49 (2007) 3, S. 238).

\section{Successful development of enterprise architecture}

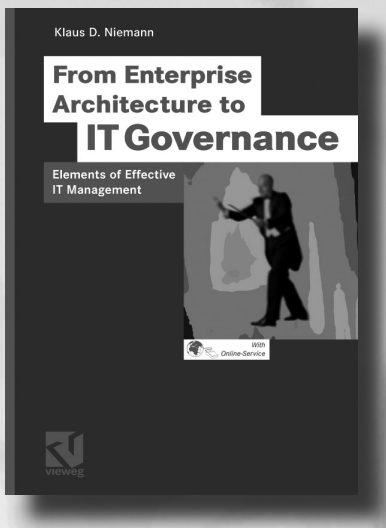

Klaus D. Niemann

From Enterprise Architecture to IT Governance

Elements of Effective IT Management

2006. xii, 232 pp. with Online-Service. Softc. EUR 56,90

ISBN 978-3-8348-0198-2

\section{Das Buch}

This book shows its readers how to achieve the goal of genuine IT governance. The key here is the successful development of enterprise architecture as the necessary foundation. With its capacity to span and integrate business procedures, IT applications and IT infrastructure, enterprise architecture opens these areas up to analysis and makes them rich sources of critical data. Enterprise architecture thereby rises to the status of a crucial management information system for the $\mathrm{CIO}$. The focused analysis of the architecture (its current and future states) illuminates the path to concrete IT development planning and the cost-effective and beneficial deployment of IT.

Profit from the author's firsthand experience - proven approaches firmly based in enterprise reality.

FAX-Bestellung 0611.7878-439

\section{Ja, hiermit bestelle ich:}

Änderungen vorbehalten

Klaus D. Niemann

From Enterprise Architecture

to IT Governance

2006. EUR 56,90 (zzgl. Versand)

ISBN 978-3-8348-0198-2

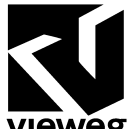

Abraham-Lincoln-Str. 46

65189 Wiesbaden

www.vieweg.de

Fax: 0611.7878-439 Geschä̈tsfführer Andreas Kösters, Dr. Rat

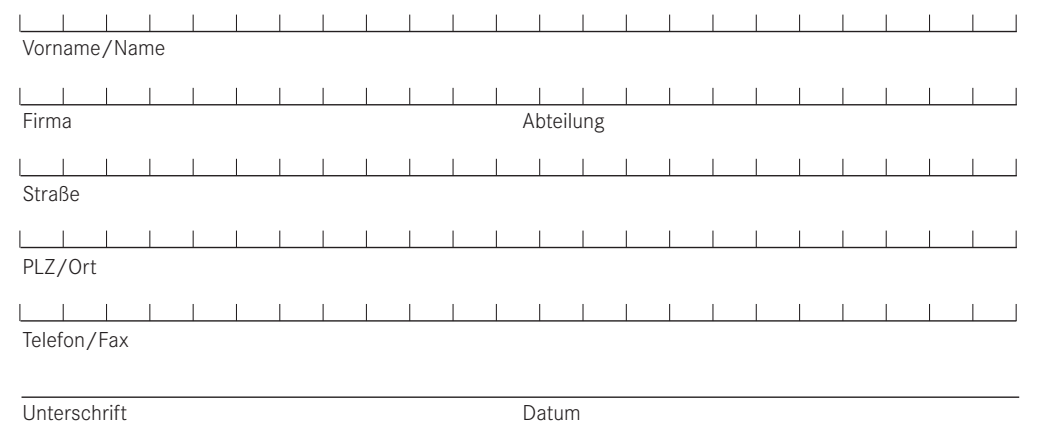

